Canadian University Music Review

Revue de musique des universités canadiennes

\title{
The Roaring Lion: Critical Musicology, the Aesthetic Experience, and the Music Department
}

\section{David Gramit}

Volume 19, numéro 1, 1998

URI : https://id.erudit.org/iderudit/1014603ar

DOI : https://doi.org/10.7202/1014603ar

Aller au sommaire du numéro

\section{Éditeur(s)}

Canadian University Music Society / Société de musique des universités canadiennes

ISSN

0710-0353 (imprimé)

2291-2436 (numérique)

Découvrir la revue

Citer cet article

Gramit, D. (1998). The Roaring Lion: Critical Musicology, the Aesthetic Experience, and the Music Department. Canadian University Music Review / Revue de musique des universités canadiennes, 19(1), 19-33.

https://doi.org/10.7202/1014603ar
Résumé de l'article

This paper argues that a number of recent responses within North American musicology to critical scholarship that has challenged disciplinary conventions have in common a deep loyalty to the aesthetic experience of music as a supreme value. The vigour with which this value is defended has close parallels in religion, and such defences have indeed sometimes resorted to explicitly religious terminology. The institutional situation of North American musicology in university music departments dominated by Western classical music instruction strengthens this ideology, which continues to resist socially oriented study of music.
All Rights Reserved (C Canadian University Music Society / Société de musique des universités canadiennes, 1998
Ce document est protégé par la loi sur le droit d'auteur. L’utilisation des services d'Érudit (y compris la reproduction) est assujettie à sa politique d'utilisation que vous pouvez consulter en ligne.

https://apropos.erudit.org/fr/usagers/politique-dutilisation/ 


\title{
THE ROARING LION: CRITICAL MUSICOLOGY, THE AESTHETIC EXPERIENCE, AND THE MUSIC DEPARTMENT
}

\author{
David Gramit
}

Discipline yourselves, keep alert. Like a roaring lion your adversary the devil prowls around looking for someone to devour. Resist him, firm in your faith...

1 Peter 5: 8-9a (NRSV)

To open with a biblical text, however time-honoured it may be for a sermon, runs counter enough to established norms for a musicological paper that it risks dismissal for a variety of reasons, ranging from mockery to affectation. By doing so, however, I am both acknowledging a text that sprang to my mind as uniquely relevant to the musicological phenomenon I will consider, and suggesting parallels between the religious discourse exemplified in the sermon and the musicological discourse that, I will argue, is a prominent feature of the discipline as institutionalized in North American universities. The methodological disputes of the past decade, and in particular the sometimes vehement reaction encountered by socially-grounded discussions of art music, have given rise to a rhetoric reminiscent of that employed by the author of 1 Peter: the tone and persistence of such reactions would suggest that there is indeed an adversary seeking to devour, and resistance is based in unwavering adherence to a foundational faith. ${ }^{1}$

Before developing this analogy and seeking to identify the nature of the faith being advocated, I will clarify my topic in relation to the discipline of musicology. I will be discussing what I have termed "critical musicology," for want of a less ambiguous label, or, more precisely, the place of that enterprise in relation to musicology as a discipline. "Musicology" as I use it here is not the broadly inclusive term used by Philip Bohlman in an essay that provides a stimulating alternative perspective on many of the issues I will discuss. ${ }^{2}$ To use the term as he does, to refer to any scholarly study of a musical phenomenon, has historical precedents but marks the discipline as open to music and

1 An earlier version of this paper was read at the conference "Bordercrossings: New Directions in Music Studies," Ottawa, March 1995.

2 Philip Bohlman, "Musicology as a Political Act," Journal of Musicology 11 (1993): 411-36. See Bohlman's discussion of his use of the term "musicology," 418-19. Although Bohlman's essay is now more than five years old, the standard practice of musicology continues to show little consideration of the issues he raises concerning the discipline's construction of music. The durability of that construction is what prompts me to investigate aspects of its motivation. 
enquiries of all sorts. As I use it, however, the term is more restrictive but also more representative of the activities most strongly associated with it: the discipline I am discussing is that which has made the European art music tradition its primary object of study, establishing strong but usually only implicit bounds not only to suitable repertoire, but also to appropriate approaches to that repertoire. My aim in what follows is to suggest an aspect of the ideological underpinning of this familiar disciplinary situation and to trace its influence on the development and reception of a critical musicology.

What, then, is critical musicology? Despite the similarity of the name I have adopted, it is not to be equated with Joseph Kerman's influential vision of musicology as directed toward the ultimate goal of music criticism, the sympathetic discussion and evaluation of individual works of music. First explicitly defined as a scholarly program in 1965, Kerman's agenda has had a substantial and continuing impact on the practice of musicology in North America, as both his own later overview of the field and the continued work of Kerman and those who have explicitly or implicitly adopted his program make clear. ${ }^{3}$ Still, despite substantial methodological and rhetorical differences from the positivistic mainstream Kerman initially opposed, his program shares crucial common ground with that mainstream, maintaining and even strengthening both its traditional focus on the canonic Western tradition and the centrality of composers and their works that characterizes that tradition. As I will suggest below, however, this is also true of some important examples of what I would term "critical musicology." Indeed, it is precisely the pervasiveness of a mode of discourse that situates the experience of listening to individual works as the essential focal point of musicological study which lends that mode extraordinary significance. While I do not propose that critical musicology should banish either close readings of works or talk of musical experience, I will claim that it must remain aware of the ideological underpinnings of these approaches and draw attention to how they can either intentionally or inadvertently limit the object of musicological inquiry in a way that excludes from the start much of what could fall within the scope of the discipline.

An earlier usage of the term in a way similar to my own makes its ambivalence clear: I have drawn my formulation from Susan McClary, who writes that "the project of critical musicology (of which feminism would be an important branch) would be to examine ways in which different musics articulate the priorities and values of various communities." McClary herself begins with Kerman's call for music criticism, but I would argue that the context in which she reiterates it amounts to a productive appropriation of that call: to shift attention from "music as aesthetic experience" (Kerman's phrase; see below for its context) to "musics" in relation to "various communities," is

3Joseph Kerman, "A Profile for American Musicology," Journal of the American Musicological Society 17 (1965): 61-69; Kerman's overview is Contemplating Music: Challenges to Musicology (Cambridge: Harvard University Press, 1985), esp. 113-54; for a more recent example of Kerman's approach in explicit comparison to recent methodological alternatives, see Kerman, "Close Readings of the Heard Kind," 19th-Century Music 17 (1994): 209-19. 
to fundamentally realign the goal and attendant methodologies of that criticism. ${ }^{4}$

Such realignment, of course, is precisely what allows for critical musicology in the sense I am using it, and McClary's own writings offer perhaps the best-known and certainly the most frequently attacked examples of this development. ${ }^{5}$ But as McClary suggested it should, critical musicology has indeed come to encompass a rich variety of approaches. I can give only a few prominent examples here. Rose Rosengard Subotnik has consistently challenged musicology to come to terms with the implications of leading thinkers of this century, from Adorno to Derrida and beyond. ${ }^{6}$ Gary Tomlinson has also explored recent critical thought in the context of a critique of musicological methodologies in the study of the Renaissance, while an extraordinary series of studies by Lawrence Kramer has explored the intersection of literary and critical theory and music. ${ }^{7}$ And Lydia Goehr's Imaginary Museum of Musical Works, although explicitly addressing issues in philosophical aesthetics, also reveals the extent to which musicology has itself overlooked the historicity and regulative function of the concept of the musical work itself. ${ }^{8}$ This questioning of tacit assumptions about the nature and impact of central practices or repertoire is a defining feature of critical musicology, a feature other authors have explored by drawing our attention to aspects of music that those central practices have obscured. So, for instance, Jeffrey Kallberg's exploration of the social implications of genre explores aspects of music's social construction not readily accessible through analysis of works, and Richard Leppert has used visual representations of music to demonstrate music's role in varied constructions of the body, power, and ideology. ${ }^{9}$ And the largely neglected dynamics of musical performance have also come under scrutiny in such work as Suzanne Cusick's analysis of the self-erasure of performer and audience in the paradig-

\footnotetext{
4See Susan McClary, Feminine Endings: Music, Gender, and Sexuality (Minneapolis and Oxford: University of Minnesota Press, 1991), 19-26; 26. On the need for music criticism, citing Kerman, see pp. 19-20.

5 Although McClary has published numerous essays both before and since, the largest single collection of her work is Feminine Endings.

6See, for example, Rose Rosengard Subotnik, Developing Variations: Style and Ideology in Western Music (Minneapolis: University of Minnesota Press, 1991), and Deconstructive Variations: Music and Reason in Western Society (Minneapolis: University of Minnesota Press, 1996).

7Gary Tomlinson, Music and Renaissance Magic: Toward a Historiography of Others (Chicago and London: University of Chicago Press, 1993). Among Kramer's works, see especially Music as Cultural Practice, 1800-1900 (Berkeley and London: University of California Press, 1990), Classical Music and Postmodern Knowledge (Berkeley and London: University of California Press, 1995), and After the Lovedeath: Sexual Violence and the Making of Culture (Berkeley and London: University of California Press, 1997).

8Lydia Goehr, The Imaginary Museum of Musical Works: An Essay in the Philosophy of Music (Oxford: Clarendon Press, 1992).

9See Jeffrey Kallberg, "The Harmony of the Tea Table: Gender and Ideology in the Piano Nocturne," Representations 39 (summer 1992): 102-32; Kallberg's essay is reprinted (along with several other relevant studies) in his Chopin at the Boundaries: Sex, History, and Musical Genre (Cambridge: Harvard University Press, 1996). For Richard Leppert, see especially Music and Image: Domesticity, Ideology, and Socio-cultural Formation in Eighteenth-Century England (Cambridge: Cambridge University Press, 1988), and The Sight of Sound: Music, Representation, and the History of the Body (Berkeley and Los Angeles: University of California Press, 1993).
} 
matic Western concert experience and Philip Brett's study of constructions of music and sexuality through the act of performance itself. ${ }^{10}$

I make no claims for the comprehensiveness of this list; it could easily be expanded. Nor do I mean to suggest that all of these authors are working together in a coherent, programmatic way; indeed, some of them have made explicit their reservations about the work of others I cite in this small list. ${ }^{11}$ Nonetheless, these examples begin to suggest the diversity of what I am including under the rubric of critical musicology: these are works that seek to read both music and musical practices "against the grain" of presumptions of autonomy, in a way that foregrounds the social construction of musical experience.

Both elements of this formulation-"social construction" and "musical experience"-are crucial. Critical musicology neither denies the relevance of intense involvement with music nor presumes it as a foundational experience. Rather, it recognizes that this form of musical experience is an essential part of the way music has been constituted in Western society; precisely because it is real it is therefore socially constructed, an object of inquiry rather than a postulate. A critical musicology begins with an acknowledgment that (to modify one of Adorno's aphoristic pronouncements) every encounter with music is "historical through and through"; 12 that is, it is contingent on culturally constructed concepts, values, and expectations that are bound up not only with an individual's society, but also with that individual's place within society, as determined by economic structures, gender roles, class values, and a host of other categories, of which we are aware to a greater or lesser degree. In this sense, regardless of the repertoire under consideration, there is no direct, unmediated contact with a musical object, for neither listening subject nor heard object are so purely and unproblematically constituted. A critical musicology thus both recognizes the intense experience we call aesthetic and explores its historical contingency, a double perspective of involvement and detachment (here Suzanne Cusick's exploration of the concert experience offers a particularly eloquent model). In Gary Tomlinson's formulation,

we might begin to interrogate our love for the music we study. This is not to say we should try to stop loving it ... It is instead to urge that we dredge up our usual impassioned musical involvements from the hidden realm of untouchable premise they tend to inhabit, and that we make them a dynamic force-to be reckoned with, challenged, rejected, indulged in, whatever-within our study. ${ }^{13}$

10Suzanne Cusick, "Gender and the Cultural Work of a Classical Music Performance," repercussions 3 (1994): 77-110, especially 80-92; Philip Brett, "Piano Four-Hands: Schubert and the Performance of Gay Male Desire," 19th-Century Music 21 (1997): 149-76.

11 See, for example, the exchange between Tomlinson and Kramer cited below, and Kallberg's discussion of McClary's work in "The Harmony of the Tea-Table," 127 n. 3.

12 Adorno's original statement was that "the truth content of works of art ... is historical through and through"; Aesthetic Theory, trans. C. Lenhart (London: Routledge and Kegan Paul, 1983), 273.

13Tomlinson, "Musical Pasts and Postmodern Musicologists: A Response to Lawrence Kramer," Current Musicology 53 (1993): 24. 
Another look at this list of authors suggests a social situation of a different kind: women predominate on the list; several of these authors (Goehr, Kramer, and Leppert) hold academic positions outside music departments; others have explicitly thematized the resistance they have encountered in dealing with established institutional perspectives. ${ }^{14}$ Those problems have come to seem less threatening over the past decade, and not only are several of these authors now senior scholars in prestigious musicology programs, but such critical musicology is also practised by a number of other well-established scholars in prestigious academic positions. Nevertheless, much critical musicology has come from scholars writing from positions that have not been the predominant ones within the discipline, and those scholars have not always found their perspectives welcome in the discipline's traditional institutional sites. If Edward W. Said's 1991 assertion that such scholarship "occupies minority if not marginal status in musicology" might seem by now to require updating to reflect critical scholarship's more established position, the appearance since that time of a variety of negative assessments of recent methodological developments serves as a reminder that musicology remains a conservative discipline whose ideological basis resists lasting change. ${ }^{15}$

Precisely the defensive vehemence of several such reactions prompts me to raise the issue. The most obvious and extreme example is Pieter C. van den Toorn's Music, Politics, and the Academy, but explicit if more cautiouslystated questions about the motivations and (perhaps already exceeded) limits of critiques of Western art music have been raised by scholars as diverse as Leon Botstein, Ralph Locke, and Ellen Rosand, the last from the privileged forum of her 1994 presidential address to the annual meeting of the American Musicological Society (see below for further discussion of these responses). ${ }^{16}$

What can account for the tenor of these reactions? One could be tempted to dismiss them as based on misunderstanding or as vocal but isolated grumblings, or as yet another ramification of musicology's consistent failure-also noted by Said-to link its object to broader political and cultural concerns. ${ }^{17}$

14See, for example, McClary, "The Blasphemy of Talking Politics during Bach Year," in Leppert and McClary, eds., Music and Society: The Politics of Composition, Performance, and Reception (Cambridge: Cambridge University Press, 1987), 14; and Subotnik, Developing Variations, 3.

15Edward W. Said, Musical Elaborations (New York: Columbia University Press, 1991), xvi.

16Pieter C. van den Toorn, Music, Politics, and the Academy (Berkeley and Los Angeles: University of California Press, 1995) - an earlier and less temperate version of van den Toorn's first chapter, which critiques Susan McClary's analysis of Beethoven, appeared as "Politics, Feminism, and Contemporary Music Theory," Journal of Musicology 9 (1991): 275-99; representative of Leon Botstein's numerous statements on this issue are his editorial, "The Future of a Tradition," The Musical Quarterly 77 (1993): 155-60, and his review of Katherine Bergeron and Philip V. Bohlman, eds., Disciplining Music: Musicology and Its Canons (Chicago and London: University of Chicago Press, 1992), Journal of the American Musicological Society 47 (1994): 340-47; Ralph P. Locke, "Music Lovers, Patrons, and the 'Sacralization' of Culture in America," 19th-Century Music 17 (1993): 149-73; and Ellen Rosand, "The Musicology of the Present," AMS Newsletter 25, no. 1 (February 1995): 10-11, 15. For related discussions from the perspective of music theory, see the special issue devoted to consideration of the "New Musicology," Music Theory Online [MTO] 2, no. 2 (March 1996); Kofi Agawu, "Analyzing Music Under the New Musicological Regime," MTO 2, no. 4 (May 1996); and Jonathan Walker, "The Deconstruction of Musicology: Poison or Cure?" MTO 2, no. 4 (May 1996).

17Said, Musical Elaborations, xvii. 
But among the authors are scholars of more than ordinary accomplishment; some have distinguished themselves in studies that are deeply concerned with music in relation to culture and politics. Their fears and misgivings merit serious consideration, which in turn can shed valuable light on the institutional situation and prospects of critical musicology itself. For, as we will see, a common fear is that a fundamental tenet of both their discipline and their institution is at stake: the double perspective-both involved and questioning involvement-that critical musicology proposes can easily be read as rejecting involvement altogether, particularly when personal experience is universalized and valorized as "the aesthetic experience"; to assert the historical contingency of that experience is to threaten one of the foundations of the discipline as it has most often been conceived. Precisely what "the aesthetic experience" signifies proves slippery at best, but statements of allegiance to it cut across the boundaries of otherwise conflicting musicological camps.

One of the clearest such statements comes not from recent controversies, but from Joseph Kerman's original call for music criticism, "A Profile for American Musicology," published in 1965:

It is my strong suspicion that the main incentive that brought most musicologists to musicology, and most theorists and analysts to their fields was ... a passion for Bach or Josquin or Beethoven or Stravinsky ... Even minutiae could be read with pleasure if they could be shown to be making a minute contribution to our essential musical experience.

A parallel situation exists on the level of the students ... What brings young men and women to musicology is an original commitment to music as aesthetic experience. ${ }^{18}$

Edward E. Lowinsky's contentious response challenged many of Kerman's assertions and goals, but more interesting for our purposes is his agreement on a central issue: "The present writer has always assumed, perhaps naively, that he was engaged with criticism ... [H]is credo has always been: 'the beginning and the end of musicological studies lie in sympathetic and critical evaluation of the individual work of art." 19

The personal experience that "sympathetic evaluation" presupposes had perhaps its most systematic exposition in Carl Dahlhaus's Foundations of Music History. According to Dahlhaus, "the fundamental problem facing the music historiologist is the relation between art and history," and one of the central issues Dahlhaus explores is how to preserve the aesthetic presence of musical works while embedding them in a historical narrative. Once again, the same terms surface, for Dahlhaus's solution, both in theory and practice, and despite the apparent even-handedness of his critiques of this form of hermeneutics, depends upon "sympathising and involving ourselves," particularly in the canonic central European repertoire that was his primary interest-and this

18Kerman, "A Profile for American Musicology," 66-67.

19Edward E. Lowinsky, "Character and Purposes of American Musicology: A Reply to Joseph Kerman," Journal of the American Musicological Society 17 (1965): 226. Lowinsky quotes his own Tonality and Atonality in Sixteenth Century Music (Berkeley: University of California Press, 1961), 72. 
despite Dahlhaus's explicit acknowledgement of the historicity of the concept of musical autonomy itself. ${ }^{20}$

Lawrence Kramer's wide-ranging and innovative discussions of music are a far cry from musicology as envisioned by Dahlhaus, ${ }^{21}$ and much of Kramer's work draws attention to the contingency of musical experience that is central to critical musicology, but it also demonstrates that aesthetic experience is so deeply rooted as the basis of musicology that even explicitly revisionist approaches take it over with significant features unchanged. This is in part due to the disciplinary past: Kerman's call for a musicology founded on aesthetic experience proved immensely attractive and has provided a grounding for much of the most innovative musicology of the past decades, and its orientation towards the practices of literary criticism encouraged scholars of music to learn from that field's methodological ferment. Kramer's background in literary studies has enabled him to do so to a degree rare among musicologists, and his work reveals that a significant part of Kerman's program remains intact. ${ }^{22}$

Kramer's recent programmatic statement-the opening chapter of his Classical Music and Postmodern Knowledge-develops a subtle and challenging theoretical framework for considering musical immediacy, seeking to demystify aesthetic experience while remaining aware of its significance: "the last thing a post-modernist musicology wants to be is a neo-Puritanism that offers to show its love for music by ceasing to enjoy it." 23 Kramer's critical practice reveals how seriously he has taken this statement to heart-critical rehearings of canonic classical compositions are central to virtually all his essays, and in a polemical exchange with Gary Tomlinson, Kramer expanded on what remains for him as the foundational experience of music:

Tomlinson in effect asks for ... the dispersal into context of what we usually grasp as the immediacy of music.

... What would happen if we gave up listening with the kind of deep engagement, the heightened perception and sense of identification, that both grounds and impels criticism? ... [T] he materiality of the music, the dynamic sensuous fullness that arguably offers a major site of resistance to ideological pressures, would be put at risk. ${ }^{24}$

20Carl Dahlhaus, Foundations of Music History, trans. J. Bradford Robinson (Cambridge: Cambridge University Press, 1983); 19, 73. As James Hepokoski notes ("The Dahlhaus Project and Its Extra-Musicological Sources," 19th-Century Music 14 (1991): 221-46), Dahlhaus was responding to methodological challenges not unlike those now facing North American musicology. It is tempting to attribute the unprecedented quantity of translations of his work to his potential to provide a response to those challenges.

21 For Kramer's own critique of Dahlhaus, see his Classical Music and Postmodern Knowledge (Berkeley and Los Angeles: University of California Press, 1995), 46-51.

22For Kerman's own favorable (if brief) evaluation of Kramer's practice, see Kerman, "American Musicology in the 1990s," Journal of Musicology 9 (1991): 142.

23 Kramer, Classical Music and Postmodern Knowledge, 17. Kramer's opening chapter, "Prospects: Postmodernism and Musicology," is found on pp. 1-32.

24Lawrence Kramer, "Music Criticism and the Postmodernist Turn: In Contrary Motion with Gary Tomlinson," Current Musicology 53 (1993): 27. 
Whether or not Tomlinson's position is here accurately represented, the ground of Kramer's scholarly pursuit is both clear and more than incidentally similar to that of Kerman, Lowinsky, and Dahlhaus. Despite his skill at relating a rich and strikingly diverse variety of materials-from literary texts and works of visual art to the gendered practices of education-to the music he considers, the ideology of aesthetic experience still shapes and limits Kramer's work: to a surprising extent the basic model of enriching the listener's experience of great works remains intact, along with the assumption that experience is the essential locus of musical meaning. ${ }^{25}$ In the process, the other essential components of musical practice-not only the ubiquitous physical discipline of practising itself, but also the personal, pedagogical, commercial, and industrial relations that help constitute musical culture-are effectively subordinated to the privileged intellectual practice of reflective listening and analysis. The relative paucity of attention that these aspects of music have attracted in musicological studies exploring the cultural meaning of classical music is perhaps the clearest evidence of the disciplinary gap between cultural studies and musicology and of the challenges still awaiting a critical musicology. ${ }^{26}$

The narrowing of that gap, however, will likely not be accomplished without resistance within the discipline, for, as I mentioned above, critical musicology has provoked a variety of defensive reactions. To move from Kramer's postmodern critique to Pieter C. van den Toorn's refutation of Susan McClary's treatment of Beethoven is indeed a jarring shift, but note that the intensity of the musical experience is for both a polemical touchstone:

With varying degrees of intensity, musical works can become objects of affection, faith, and love. They can speak to us directly, cut through to the heart without deliberation, without verbal approximation. And they can speak to us as individuals, single beings, not as representatives compromised by partisanship. Indeed, they may appear to serve no other purpose than that of the relationship that is struck ... [T] willed nor forced but is entered into freely, naturally, and spontaneously. Although not necessarily private, it is personal, inward, and spiritual. ${ }^{27}$

In this view, to investigate such a relation is to destroy it. Leon Botstein's claim for the essential and self-evident superiority of works like The Marriage of Figaro over those like The Phantom of the Opera is rooted in a similar faith in the power of the experience of the canonic repertoire. ${ }^{28}$ And although both

25A more recent critique of Tomlinson, this one by Richard Taruskin, is based largely on challenging Tomlinson's readings of his theoretical sources, but also makes clear in passing his rejection of what he sees as Tomlinson's lack of "a critical interest in what I have called (after Charles Seeger) 'the fine art of music." See "Others: A Mythology and a Demurrer (By Way of a Preface)," in Defining Russia Musically: Historical and Hermeneutical Essays (Princeton, N.J.: Princeton University Press, 1997), xxx.

26I have explored this point in greater detail in "Musicology, Commodity Structure, and Musical Practice," in Crosscurrents and Counterpoints: Offerings in Honor of Bengt Hambraeus at 70, ed. Per F. Broman, Nora A. Engebretsen, and Bo Alphonse, Publications from the University of Gothenburg Department of Musicology, vol. 51 (Gothenburg: Gothenburg University, 1998), 22-34.

27 van den Toorn, Music, Politics, and the Academy, 11-12.

28 Botstein draws this comparison in his review of Disciplining Music, 345. On the liberatory impact 
more clearly focused and less contentious than Botstein or van den Toorn, Ralph Locke cites a by-now familiar authority for rejecting Lawrence Levine's characterization of concert music audiences in the nineteenth century:

This account—and it would be easy to find many similar ones—does not give adequate credit to the active and often critical/creative internal participation in the musical artwork that can be functional parts of both performing and listening. It brackets out what many of us would recognize as the musical experience itself. ${ }^{29}$

Here the definite article assumes crucial importance: adequate scholarship would require acknowledgment not of $a$ musical experience, but of the musical experience-and the paradigm of that experience is the contemporary academic's encounter ("many of us") with the canonic Western concert repertoire. The naturalization of that encounter is responsible, I would argue, for much of what music history explicitly and implicitly values. ${ }^{30}$ If the musical experience is universal, then music that does not evoke it in us is flawed, or at best peripheral. As Philip Brett has pointed out in another context, the inclusiveness of such assertions of collective agreement masks an implicit but very real exclusion of all who hear differently. ${ }^{31}$ On the other hand, music amenable to the concert experience becomes the legitimate object of musicological inquiry - and witnesses who describe what can be read as a similar experience of music serve to confirm an implicit claim to universality. So, for instance, the passages from the Confessions of St. Augustine that relate his experience of the power of music and the struggles of conscience that result have become by far the most familiar patristic writings on music, evidence that a truly sensitive listener in the fourth century shares something of central importance with us; the past becomes a reassuring mirror of the present. To encounter Augustine in standard music history texts ("when it happens to me to be more moved by the singing than by what is sung, I confess myself to have sinned criminally, and then I would rather not have heard the singing"32) is to recognize our own experience of music's power, constrained only by religious reservations that prevent its full unfolding. The experience is a constant and so need not (or may not-or ought not) be investigated; only circumstances more or less conducive to it are subject to alteration and are therefore suitable objects of scholarly enquiry.

of encounter with the classical repertoire, see also "The Future of a Tradition."

29Locke, "Music Lovers," 169.

30Gary Tomlinson has suggested that a teleological view of music history as progressing towards that repertoire is responsible for a misleading construction of music in the Renaissance (Music in Renaissance Magic, 14-20); I would argue that this naturalization of the musical experience is equally responsible for the shape of music history in its traditional form.

31 Brett is discussing Kofi Agawu's response to the controversy surrounding Schubert's sexuality. See his "Piano Four Hands," 151-53.

32 Augustine, Confessions X, cited in Donald Jay Grout and Claude V. Palisca, A History of Western Music, 4th ed. (New York: Norton, 1989), 36. Piero Weiss and Richard Taruskin, eds., Music in the Western World: A History in Documents (New York: Schirmer Books, 1984), 31-32, also cites the same passage. 
Augustine and the constraints of religion bring us full circle to my opening religious analogy, to which I now return, for the conception of faith with which Augustine is associated closely parallels the musicological ideology I have outlined. Just as in Augustinian theology and epistemology faith is the essential starting point, what one scholar has termed "that indispensable adhesion without which nothing can be apprehended," 33 so in musicological discourse a faith grounded in the centrality of the individual aesthetic experience of the musical work becomes the foundation of all other inquiry, so basic that it rarely comes to direct expression except in polemics, when a declaration of orthodoxy or an accusation of heresy is called for. ${ }^{34}$

Terms like orthodoxy and heresy may seem extravagant in the context of musicology, but defenders of the musical experience have more than once opted for religious language. John Rahn, for example, who cites postmodern authorities including Lacan, Kristeva, and Rorty to arrive at a defence of the musical experience as direct, personal, and unmediated, offers a sequence of images for the immediacy of that experience that begins with the sexual union implied by the striking (and oddly antiquated) image of "coupling" and culminates in a mystic oracle:

But during the time I am coupled with the music, there is little or no semeiosis going on. The music and I are too involved with one another for a space to open up between us at any time, so that I could constitute a separate it as a sign ... There is in music-time no monologue in me about the music which is linguistic, no logos in mousiké. Those who sat upon the Delphic tripod over a Gaea cleft for Apollo were trained to speak during the divine afflatus, but they never made sense. It was the priests of Apollo who, like latter-day psychomusicometricians, stood apart watching the Pythoness in her trance: it was they who pretended to make sense of her protocol report of her experience. $^{35}$

Although it makes its points through irony rather than mysticism, Ellen Rosand's presidential address also reaches for a religious image in a striking context. Having acknowledged (in terms reminiscent of Kerman's) the necessity of "passionate engagement" and "personal involvement" with music, she goes on to warn against a "certain displacement of meaning," as scholars increasingly seek to contextualize music:

Some of us may feel the necessity of restoring the balance, of returning once again to the musical work, to discover the affective structures of its operation.

Some of us indeed may feel the need to fetishize our objects anew.

33The New Catholic Encyclopedia, s.v. “Augustine, St.," by O. J.-B. du Roy (New York: McGraw Hill, 1967), 1:1052.

34 Patrick McCreless, in his review of Music, Politics, and the Academy in MLA Notes 53 (1997): 755 , has also noted that van den Toorn's uncritical acceptance of the "stability and transcendence of the work" requires readers "by default to accept it as a matter of faith."

35John Rahn, "Differences," Perspectives of New Music 31 (1993): 58-71; 66-67. 
Such language is well within the mainstream of musicological discourse, although the call to "fetishize anew" is unusually straightforward. The next paragraph, however, draws clear boundaries, aided by a concluding image of the sacred that serves both as warning illustration and as comic relief:

But not all of them. As the full range of the world's musical utterance is opened up to serious critical investigation, in our own work and in the classroom, we need to recognize that our interest in certain kinds of music may be primarily and essentially sociological. Whether or not such music has redeeming aesthetic value seems somewhat beside the point. The dilemma may be summed up through one not uncommon classroom encounter with the student unable to distinguish between the Madonna and Madonna.

Note that religious language becomes explicit only after its realm is delimited; that which is set apart must be set against something which is not. Music of "primarily and essentially sociological" interest is distinct from that which possesses "redeeming aesthetic value." 36 (Note the ambiguity of the formulation: is the music redeemed by its aesthetic value, or is the listener redeemed by the experience of the music?) If the supreme value of the personal aesthetic experience is here respected, as a corollary so too is the primacy of the canonic repertoire that can reliably produce it. Because sociological interest is separable from the interest that motivates study of redemptive, aesthetically valuable music, the double perspective of critical musicology is unnecessary. ${ }^{37}$

That art, and music in particular, assumed for many a quasi-sacred status in the nineteenth century is an often noted (if still under-studied) phenomenon. ${ }^{38}$ The roots in Romantic aesthetics of the belief that the essence of music is fundamentally different from verbal language and representational art-and thus essentially unspeakable - are also common knowledge in the discipline. The reactions I have cited, however, suggest not only that these ideas are a part of the field's accepted knowledge, but also that they serve as enablers of the discourse, helping to constitute what can stand as knowledge within the field as well as the means by which that knowledge can be constructed and validated. Just as eighteenth-century German advocates of a canon of serious literature adopted the strategy of setting apart a few authoritative works for reading, rereading, and reflection that had long been the model for religious texts, so much of the discipline of musicology has been predicated on the intensive experience of great works. ${ }^{39}$ That experience is either described (in studies

36Rosand, "The Musicology of the Present," 11. Rahn, "Differences," 68, also concludes with a stipulation that the music that validates the musical experience must be "of great complexity, depth, and power of originality."

37The tension between sociological and musicological approaches is the focal point of Charles Rosen's review of Tia DeNora, Beethoven and the Construction of Genius: Musical Politics in Vienna, 1792-1803, in The New York Review of Books 43, no. 18 (14 November 1996): 57-63, and the two authors' subsequent exchange in the same publication (44, no. 6 [10 April 1997]: 66-67). Even Susan McClary takes pains to distinguish her approach from a sociological one (Feminine Endings, 30-31).

38The most extensive discussion is in Dahlhaus, The Idea of Absolute Music, trans. Roger Lustig (Chicago and London: University of Chicago Press, 1989), 78-102.

39The development of the German literary canon is discussed in Martha Woodmansee, "Aesthetics 
aligned with music criticism) or assumed (in much of what has come to be termed "positivistic" scholarship); to challenge that experience explicitly, however, is to overstep the bounds of the acceptable. Under these disciplinary circumstances, when Timothy D. Taylor marks the conclusion to the introductory chapter of his recent Global Pop: World Music, World Markets by writing "but we have gone on too long without music," the effect is strikingly like a ritual invocation assuring musicological readers that, despite the study's unconventional subject and extended introductory discussion of the music industry, its real subject falls within the realm of orthodoxy: it is nothing other than the "music itself." 40

From this perspective, we can see why a critical musicology-one that treats the foundational experience not as an article of faith but as the focus of inquiry - could both be met with suspicion and calls to discipline and itself be constrained to adopt the form of reflection on canonic works. Like the God of more overtly religious faith, the aesthetic experience of music functions in musicological discourse to centre what Derrida, in one of his most familiar early texts, called "a play based on a fundamental ground, a play constituted on the basis of a fundamental immobility and a reassuring certitude, which itself is beyond the reach of play." ${ }^{11}$ Extending play to that fundamental ground threatens the stability of the structure itself and, equally importantly, of those who have invested themselves in it.

This perspective suggests that the resistance critical musicology has met with is not incidental, nor is the fear that something fundamental is under scrutiny inaccurate. From the perspective of an "orthodox" musicology, the roaring lion is indeed "looking for someone to devour." Once again, I suggest that the parallel with religion is not as frivolous as it first appears, for what is at stake in both instances is the continued existence of a locus of supreme value - of an individual soul. That is, the object of the faith constituted in the musical experience is a realm (at least potentially) uncontaminated by the claims of material, everyday life-in short precisely the soul, as Marcuse sketches it in "The Affirmative Character of Culture":

and the Policing of Reading," in The Author, Art, and the Market: Rereading the History of Aesthetics, The Social Foundations of Aesthetic Forms Series (New York: Columbia University Press, 1994), 87-102, esp. 99-100. See also Woodmansee, "The Interests in Disinterestedness: Karl Philipp Moritz and the Emergence of the Theory of Aesthetic Autonomy in Eighteenth-Century Germany," Modern Language Quarterly 45 (1984): 22-47.

40Timothy D. Taylor, Global Pop: World Music, World Markets (New York and London: Routledge, 1997), 31. The remainder of Taylor's study (with the exception of its brief concluding chapter) does indeed follow musicological convention in focusing on individual artists and their works, albeit in the context of the global music industry. As a whole, the book neatly illustrates the tensions I am here exploring, hovering between the conventions of music criticism in the traditional sense, in which culture and economics form a kind of backdrop over against which to hear the music that forms the book's self-evident subject matter, and a critically informed and reflective consideration of music's place in that culture.

41 Jacques Derrida, "Structure, Sign, and Play in the Discourse of the Human Sciences" (1966), reprinted in David Lodge, ed. Modern Criticism and Theory: A Reader (London and New York: Longman, 1988), 109. 
The soul is sheltered as the only area of life that has not been drawn into the social labor process ... The ideal that man, individual irreplaceable man, beyond all natural and social distinctions, be the ultimate end ... can be represented, in a society determined by the economic law of value, only by the soul and as spiritual occurrence. All else is inhuman and discredited. The soul alone obviously has no exchange value. ${ }^{42}$

Despite its age, Marcuse's account retains its relevance in a discipline in which appeals to high culture still resist problematization; few authors have so acutely analyzed the appeal to an intangible, transcendent meaning in objects of that culture, and precisely this is at issue in the defence of the musical experience. Even though critical musicology as I have discussed it here remains limited in both scope and quantity, to the extent that it threatens the sanctity of that experience, it does indeed seek to devour the soul as ideological construct, and with it the structure of valuation and meaning which that experience anchorsthe place of Western music history and its canon as the centre and ground of the musicological enterprise.

A final consideration concerns the institutional locus of both critical musicology and the disciplinary reaction to it. If the issues I have raised were solely a matter of disagreements between individual and independent musicologists, or even between imagined and amorphous "interpretive communities" based on free association of like-minded individuals, then so parochial a squabble could scarcely claim relevance to anyone whose musical or academic interests lay in areas other than the small portion of the world's musics with which musicology has primarily concerned itself. Indeed, the "relative isolation of historical musicology" forms one of the bases of John Shepherd's critique of the discipline and his call for the reformulation of music studies. ${ }^{43}$ However, just as music "exists within sets of institutional practises and taste formations that render it 'popular' to specific groups of practitioners and users," 44 so does musicology, and any attempt to reformulate the discipline in its institutional setting-the university, in which music departments are privileged as the centre of musical studies-must take account of those institutional practises and taste formations.

Most musicologists-to begin with the obvious-do indeed work in music departments, with whose other inhabitants they have often existed in an attitude of uneasy mutual suspicion. However, just as it cuts across musicological party lines, loyalty to the musical experience unites scholar and performer as well. Those departments, after all, whether founded as training schools for musicians in the classical tradition or as ancillary departments to provide members of an elite-in-training the benefits of high culture, have historically cultivated the aesthetic experience by training both performers and audience members, firm

\footnotetext{
42Herbert Marcuse, "The Affirmative Character of Culture," in Negations: Essays in Critical Theory (Boston: Beacon Press, 1968), 108-9.

43John Shepherd, "Popular Music Matters: Challenges to Musicology," Stanford Humanities Review 3, no. 2 (autumn 1993): 17.

44 Ibid., 19.
} 
in the received and usually unstated faith. Thus, not only do musicologists participate in the cultural formation of the tastes of students, but to the extent that their work helps buttress the foundational role of the musical experience, they also contribute to the stability of an institution whose structure is predicated on values that would exclude the sort of revision that Shepherd and others have advocated. To be sure, in most departments, courses in other musics exist and may even be required of majors, but they most often remain peripheral both in terms of role in the curriculum and in faculty representation.

To claim as I have that musicology reinforces the commitment of music departments to the musical experience as ideology may seem extravagant (or even deluded) to anyone who has experienced traditional music history courses, in which the parade of dates, composers, forms, and work lists may appear designed to avoid discussion of any encounter with music as sound, whether as "aesthetic experience" or not. But might this format in fact be the result, not of a perverse desire to silence music, but rather of proceeding on the basis of just the faith in the experience of music that I have been discussing? Because the experience is central and immune to description, music history has little alternative but first, to present works and the information that surrounds them once so reified-for the musical experience begins with music as work rather than as human behaviour; and second, to avoid discussion of the experience those works permit, an experience no words can adequately describe. Unease about the degree to which other musics threaten to encroach upon curricular time formerly devoted to the Western canon-as reflected, for instance, in Mary DuPree's question, 'is a music student 'literate' if s/he graduates from a music program having studied less, in the case of Beethoven, than his third, fifth, and ninth symphonies, plus a few other works from representative genres?"45 - is stated in terms of works, of the survival of the canon, but may express a more basic fear for the survival of the musical experience itself. The resulting, all too familiar conflation of "music history and literature" as a single subject makes critical musicology all the more difficult to mesh with the institutional and curricular place of the discipline: the always implicit and occasionally explicit expectation that music history courses exist to familiarize students with the canon entails a pedagogical mode that can easily frustrate attempts to consider music as an historical, cultural practice dependent on a wide range of social relations. To challenge this institutional inertia is even more difficult because most musicologists-and I am no exception-are products of this same system who have indeed, as Kerman suggested, been moved and shaped by this same musical experience; to challenge institutional practices is also to challenge our own makeup.

Because our situation intertwines the individual and the institutional, the double perspective of critical musicology can lead to an analogously complex relation to the university music departments in which most musicologists are employed. Some may continue to resolve this tension by finding other sites for

45Mary DuPree, "Beyond Music in Western Civilization: Issues in Undergraduate Music History Literacy," College Music Symposium 30 (1990): 104. 
their academic careers, others by a kind of in-but-not-of stance in relation to the ideological goals of those departments-or, to express it less loftily, by living with continuing tension between scholarly practice and institutional pedagogical expectations. As disciplinary boundaries become more fluid, still other solutions will no doubt be found. Wherever it is practised, however, the task of a critical musicology is not to dismiss the musical experience, but rather to pluralize it and to begin to write the histories of those experiences and the practices that enable them. Unless the discipline we know as musicology (in my narrow sense) adopts such a critical stance, broader uses of the term (like Philip Bohlman's) will continue to project an inclusiveness more imaginary than actual.

\begin{abstract}
This paper argues that a number of recent responses within North American musicology to critical scholarship that has challenged disciplinary conventions have in common a deep loyalty to the aesthetic experience of music as a supreme value. The vigour with which this value is defended has close parallels in religion, and such defences have indeed sometimes resorted to explicitly religious terminology. The institutional situation of North American musicology in university music departments dominated by Western classical music instruction strengthens this ideology, which continues to resist socially oriented study of music.
\end{abstract}

